\title{
Mitigating dry season food insecurity in the subtropics by prospecting drought-tolerant, nitrogen-fixing weeds
}

\author{
Finlay A. A. Small and Manish N. Raizada*
}

\begin{abstract}
Subtropical regions experience an extended dry season, which inhibits the growth of most crops, and as a result there is seasonal scarcity of food and fodder. Globally, almost 600 million smallholders and landless laborers experience hunger in the dry season. This situation is expected to worsen, as water shortages are expected to impact up to twothirds of humanity between 2010 and 2050. A second challenge is that 45\% of the world's agricultural land is sloped and vulnerable to intense surface runoff during the transition from the dry to rainy season (e.g., monsoon). Erosion, along with nutrient mining, contributes to a net loss of soil fertility. Drought-tolerant legumes can mitigate these challenges. Legumes form symbiotic relationships with microbes that can sequester atmospheric nitrogen gas as ammonia, a process termed biological nitrogen fixation (BNF). As a result of BNF, legumes are rich in nitrogen, which is a building block of edible protein and organic nitrogen fertilizer to replenish soils. Leguminous cover crops can be used as food/feed, and as a tool to reduce the need for synthetic fertilizers, prevent erosion, and suppress undesired weeds that grow on bare, dry soil that otherwise cause female drudgery. Unfortunately, cover cropping is not a traditional practice in most subtropical regions and BNF is inhibited by drought (dry season). Subsistence farmers around the world would benefit from nutritious and drought-tolerant cover crops that can sustain nitrogen fixation in the dry season. Here, we propose that neglected crops in addition to native and naturalized plants that persist in the dry season, often considered to be weeds, may be utilized for the development of new cover crops. A detailed framework is presented for the identification, characterization, and selection of such species. As a case study, the framework was applied to the mid-hills of Nepal. A literature review, stakeholder interviews, and field site visits with farmers informed the selection of 78 candidate dry season leguminous cover crop species. It is hoped that this innovative approach will serve as a model to help alleviate food/feed shortages and improve the livelihoods of subsistence farmers in the global subtropics.
\end{abstract}

Keywords: Subtropics, Drought, Soil erosion, Malnutrition, Livestock, Cover crop, Legume, Nitrogen fixation, Food security, Subsistence farmer

\section{Background}

The challenge of seasonal drought on agricultural productivity in the global subtropics

Subtropical regions experience an extended dry season, which inhibits the growth of most crops, and as a result the scarcity of food and fodder is a seasonal event [1]. Globally, almost 600 million smallholders and landless

*Correspondence: fsmall90@gmail.com; raizada@uoguelph.ca Department of Plant Agriculture, University of Guelph, Guelph, ON N1G 2W1, Canada laborers experience seasonal hunger and food insecurity in the dry season [2]. Intense solar radiation at the equator generates convection currents that draw moisture from the subtropics, diverting precipitation and influencing the formation of deserts (Fig. 1) - the global subtropics are especially vulnerable to freshwater shortages as a result. Deserts like the Kalahari and the Sahara in Africa, which flank a moist equatorial belt, illustrate this phenomenon. Many of the most vulnerable subsistence farmers live in the subtropics where there is an extended dry season: South Asia, East and Sub-Tropical Africa, 


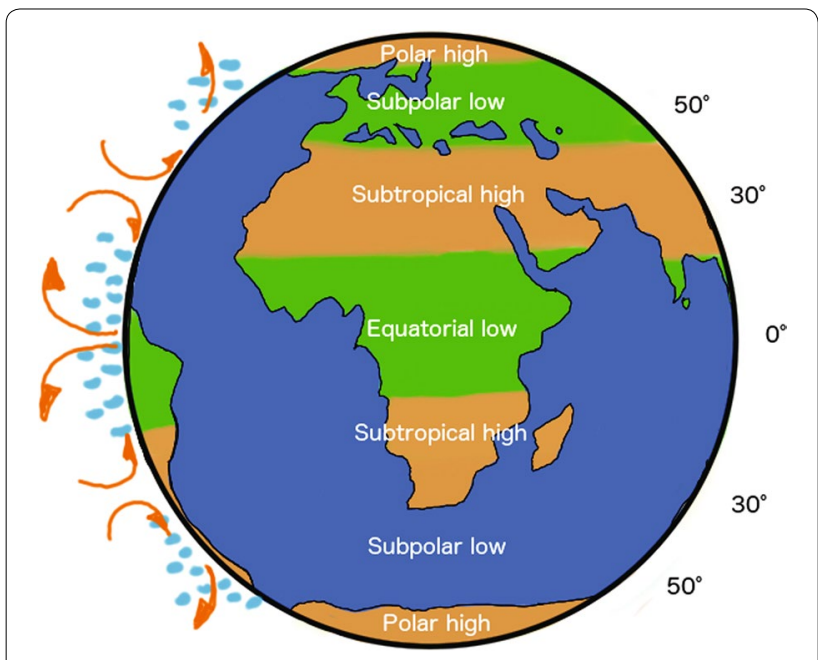

Fig. 1 Global water dynamics. Global rainfall patterns, temperature, Earth's curvature, and rotation influence the formation of deserts in the subtropics. As the Earth rotates, convection currents carry moisture from the subtropics to the Tropics where heat causes the air to rise, and moisture to condense, leading to rainfall near the equator and dry zones in the flanking subtropics

Central America, and Caribbean islands such as Haiti. Many of these regions are characterized by seasonal rain and drought (Fig. 2), resulting in seasonal malnutrition $[1,3,4]$. Exacerbating these challenges is seasonal migration, a global problem in areas with an extended dry season. Scarce resources, unpredictable climate, food insecurity, and drudgery motivate migration from rural areas into cities $[5,6]$. Seasonal migration of males worsens the labor deficit of farming families; women and children are forced to undertake laborious farm tasks

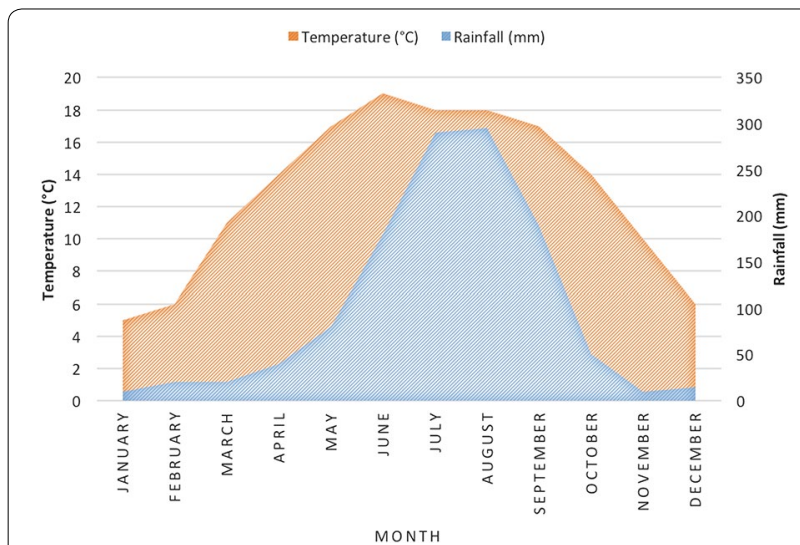

Fig. 2 Example of a subtropical climate that experiences an extended dry season. The average monthly temperature and rainfall in Nepal are shown (1990-2009). Nepal experiences a severe seasonal drought from October to April, during which farmers are challenged to cultivate crops utilizing residual soil moisture. Source: www.worldweatheronline.com like planting, weeding, and harvesting [6]. As a result of these factors, communities in the global subtropics experience exacerbated poverty, hunger, and malnutrition; eradicating this extreme poverty and hunger is the number one target of the United Nations Millennium Development Goals [7].

Producing food with scarce water and land resources is a major challenge in dry and semiarid climates around the world [8]. Drought-tolerant crops that enhance soil fertility also have the potential to mitigate agronomic challenges in the dry season [9]. Selecting locally adapted plant species represents an approach to developing a dry season cropping system that can contribute to food security, the conservation of scarce resources and ultimately alleviating poverty [10]. The objectives of this paper are: (1) to review the agroecological challenges of the dry season for subsistence farmers in the subtropics; (2) to introduce the concept of biological nitrogen fixation and leguminous cover crops; and (3) and to explore the concept of prospecting droughttolerant, nitrogen-fixing weeds as novel resources for the development of cover crops. Nepal is used as a case study for a framework that should be applicable to subtropical regions around the world. The paper uses accessible language and provides background concepts facilitate dissemination to a wide audience including social scientists and policy makers.

\section{The challenges of subsistence farming}

The majority of families in the global subtropics are smallholders or subsistence farmers [5]. There are more than 386 million small farms ( $<2$ ha) estimated worldwide, and the vast majority are family farms [11]. Subsistence farmers are challenged to grow enough food for their family on little land, often with degraded soil, and poor access to water [12]. Furthermore, the food produced by subsistence farmers is usually consumed within the household and traded within the immediate community, and rarely sold for profit. Subsistence farmers are typically isolated, without access to markets, and as a result, they do not have the capacity to generate income from their farming activities [5]. Without money, subsistence farmers cannot mitigate the challenges of degraded soil and poor access to water by purchasing external inputs like fertilizers and improved seed [12].

\section{Climate change further threatens the livelihood of subsistence farmers}

Climate change is a threat to all of humanity, and communities of subsistence farmers in the subtropics are among the most vulnerable [5]. Water scarcity is expected to affect up to two-thirds of people on Earth between 2010 and 2050 [13]. Some traditional practices of subsistence 
farmers become inappropriate as the climate changes rapidly [5]. Furthermore, subsistence farmers have limited access to agricultural inputs, improved techniques and technologies (e.g., drip irrigation); combined, smallholder farmers have a limited capacity to adapt to climate change [5]. Knowledge and technical interventions that permit adaption to a changing climate are needed to sustain the livelihoods of subtropical subsistence farming communities [5].

\section{Monsoon rains drive soil erosion on agricultural terraces in Nepal and around the world}

The loss of soil fertility occurs through erosion by wind and water as well as leaching of mineralized nutrients, a phenomenon that is worsened during the monsoon season [14]. Approximately 45\% of the world's agricultural land has a slope with a grade greater than $8 \%$, of which $9 \%$ is especially steep with a grade of over $30 \%$; these slopes are extremely vulnerable to soil erosion [8]. A United National Environmental Programme (UNEP) study estimated the annual economic losses due to soil erosion and the loss of soil fertility in South Asia at $\$ 600$ million and $\$ 1.2$ billion USD, respectively [15].

In Asia, soil erosion on hillsides is worsened during the monsoon season and from the transition from the dry season to the monsoon season [14]. Throughout most of South Asia, monsoon rains proceed the dry season; in the summer, southwesterly winds blow moist air from the Pacific and Indian Oceans across South Asia and inundate the region with rains that support the growth of major crops [16]. During the extended dry season, bare, fallow soil forms a surface crust as moisture evaporates; hence, when the monsoon season begins, the rainwater cannot percolate through the soil crust, resulting in surface runoff, especially on sloping land [17]. A study in the mid-hills of Nepal observed that monsoon rains explained between 53 and $83 \%$ of the variance $\left(R^{2}\right)$ in runoff [14]. The loss of soil fertility on agricultural terraces is associated with decreased crop yields, more weeds, and thus more drudgery [18]. In Nepal, some 20-50 tonnes of soil per hectare are estimated to be eroded each year from fields in the hills and mountains, while up to 200 tonnes per hectare per year may be lost in some highly degraded watersheds, resulting in crop yields in these areas diminishing by $8-21 \%$ in the 25 years preceding 1995 [8]. Farmers that cultivate terraces cut into the hillsides are particularly vulnerable because the livelihood of the family depends on maintaining productivity on unstable soil; landslides and loss of soil fertility put the farmers life and livelihood in peril [12]. Climate change is predicted to cause more severe weather events such as intense rainstorms, which will further increase erosion on sloped lands [19].

\section{Cover crops mitigate erosion on sloping lands}

Cover crops, either living or used as mulch, prevent erosion by protecting sloped bare soils, which are abundant following fallow periods (e.g., dry season), from the impact of raindrops and the force of blowing winds; these forces disintegrate aggregates on the soil surface, which are then lost to runoff and leaching [20-22] (Fig. 3). Cover crops with fibrous roots bind aggregates of loose sandy soil and assimilate mineralized nutrients, retaining valuable crop nutrients within the agroecosystem [23]. Compact soils have smaller pores and poorer water infiltration, and as a result they are more vulnerable to erosion by runoff; plants with a large taproot (e.g., fodder radish) create large pores in compact soil to improve water infiltration [24].

\section{Nutrient mining is a problem in the subtropics}

Nutrient mining is a serious problem in the global subtropics; nitrogen, phosphorus, and potassium (NPK) along with other nutrients are harvested with the crop biomass and lost through leaching and erosion, but not replaced [25]. As a result, most subsistence farmers cultivate land that is deficient in one or more primary crop nutrients [9]. Nutrient replacements such as synthetic $\mathrm{N}$ fertilizers are expensive to produce and must be shipped long distances and down the value chain to reach remote areas; as a result, these inputs are not affordable and often not accessible to subsistence farmers [120]. Insufficient quantities of crop nutrients lead to crop malnutrition and disease as well as an increased number of opportunistic weeds (e.g., as a result of poor soil cover), ultimately reducing crop yield and increasing the labor input requirement (e.g., for weeding) [14].

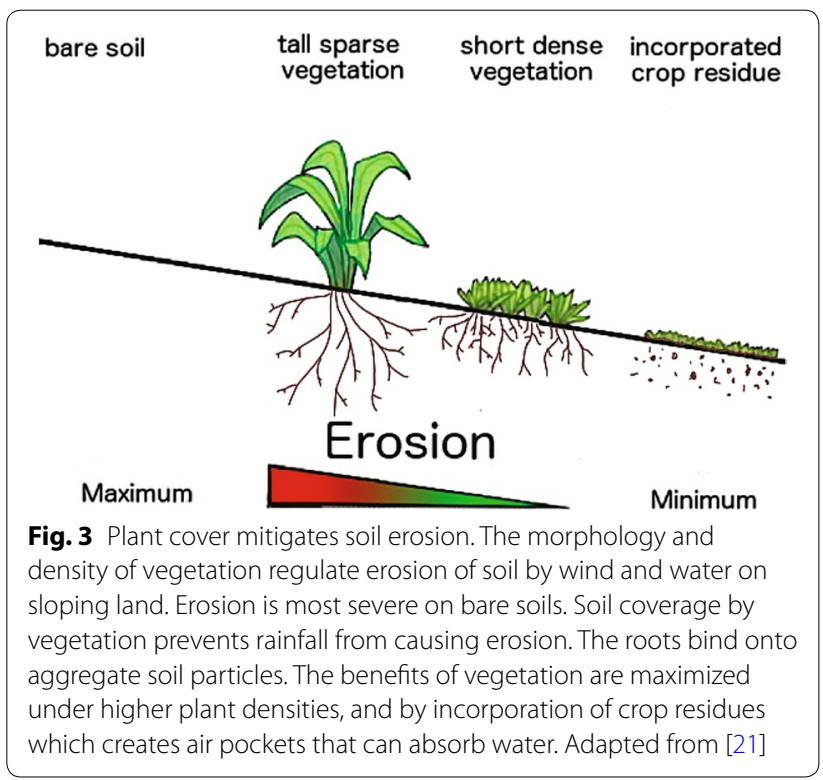




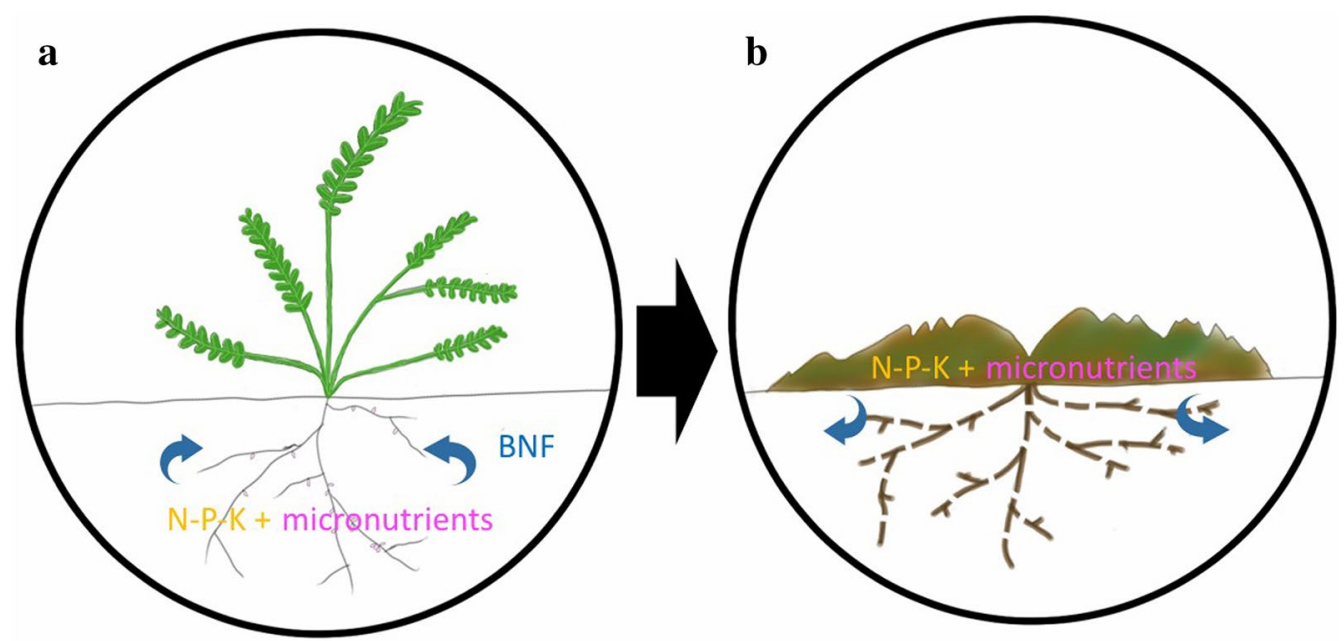

Fig. 4 Cover crops sequester nutrients and produce rich crop residue. a Crop nutrients are sequestered by cover crops and stored in their tissues instead of being lost (e.g., leaching, erosion, and volatilization) and/or unavailable. $\mathbf{b}$ The nutrient-rich crop residue acts as a mulch or compost through decomposition to benefit the subsequent crop. BNF, biological nitrogen fixation; $N$ nitrogen; $P$ phosphorus; $K$ potassium

The utilization of synthetic $\mathrm{N}$ fertilizers is associated with water pollution and eutrophication as well as air pollution from greenhouse gases like ammonia and nitrous oxide [26]. The production, transport, and utilization of synthetic $\mathrm{N}$ fertilizer consume more energy than any other aspect of agricultural plant production worldwide [26]. Continents with the majority of the world's subsistence farmers (Africa, Asia, Central and South America) account for about $75 \%$ of the total fertilizer $\mathrm{N}$ consumed [27]. Exclusive reliance on synthetic N fertilizers is a challenge to subsistence farmers who cannot afford to purchase external inputs [28]. Finding free and renewable sources of $\mathrm{N}$ fertilizer has the potential to uplift and sustain the livelihoods of subsistence farmers.

\section{Biological nitrogen fixation augments the soil $\mathrm{N}$ pool}

A hallmark of legumes is that they form symbiotic relationships with rhizobia bacteria in root organs (nodules) where the rhizobia convert atmospheric nitrogen gas into ammonia, a process termed biological nitrogen fixation (BNF) [29]. Legumes can be edible by humans (i.e., grains such as lentils), grown as a forage for grazing livestock, for soil cover (cover crops), and/or for residue incorporation into soil (green manures), though these functions are not mutually exclusive. Decomposition of non-harvested legume tissues (e.g., roots) deposits organic nitrogen into the soil to benefit nearby crops in the short term and soil fertility in the long term (e.g., to assist cereal crops) not only by depositing nitrogen but also soil organic matter (SOM) [26, 30] (Fig. 4). For this reason, legumes like beans are commonly planted with grasses such as maize or wheat [31]. The benefits of BNF can be accomplished through the use of legumes as intercrops, cover crops, and/or green manures $(\mathrm{CC} / \mathrm{GM})$. In the subtropics, the benefits of CC/GM are usually limited to the wet season, because by the end of the subsequent dry season the organic matter has already decomposed and nutrients including $\mathrm{N}$ and $\mathrm{P}$ are lost to leaching; the subsequent crop does not benefit [32].

\section{Biological nitrogen fixation is limited in the dry season}

The nitrogen fixation process is influenced by complex interactions between the community of microorganisms, plants, and the environment [33]. A major limitation of BNF is drought; water deficiency has been shown to reduce nodule activity and the survival of rhizobia in soil [34]. Annual legume cover crops, green manures, and forages have been used to the benefit of subsistence farmers in the subtropics around the world; however, the efficacy of many of these crops is limited in the dry season if irrigation is unavailable [32, 35]. Drought tends to inhibit nodulation and BNF in plants more than rhizobia [36]. Drought limits rhizobia inoculation by inhibiting root hair colonization [37]. Rhizobia populations tend to be lowest under desiccated conditions and increase as moisture availability increases [38]. Plant accessions and rhizobia strains both vary in sensitivity to drought $[33,36]$. Therefore, improving legume productivity in arid climates must involve selecting combinations of stress-tolerant cultivars and rhizobia [39]. There is a global effort to discover, select, and improve legumes and rhizobia with improved biological nitrogen fixation as a renewable source of fertilizer for subsistence farmers [39]. 
Weeds take advantage of bare soils during the dry season Opportunistic wild plants emerge at the onset of the dry season and take advantage of the residual soil moisture and nutrients to complete their life cycle. The reserve of weed seed is increased in the subsequent season, increasing the labor requirement of a difficult farm activity. An assessment of drudgery in northern India indicated that weeding is the second most laborious crop activity conducted by women, demanding up to $1110 \mathrm{~h}$ per year [40]. Planting leguminous cover crops in the dry season can alleviate weed pressure, reduce drudgery, enhance soil fertility, and provide nutrients to the subsequent crop.

Crops in the subtropics suffer from pests and diseases More than $40 \%$ of potential food production globally is lost each year to weeds, pests, and diseases [41] including problematic pests (e.g., locusts and nematodes) in the subtropics [42]. The threat and impact of crop failure is exacerbated for subsistence farmers in remote hilly and mountainous regions without access to inputs for crop fertility and protection [5]. The use of CC/GM and mulching has been shown to suppress pests like pathogenic nematodes as well as diseases [43, 44].

Cover crops and crop rotations suppress weeds, pests, and disease Crop rotations can suppress pests, diseases, and weeds [45-48]. Cover crops can suppress the growth of undesired weeds by competing for light and exuding compounds that temporarily inhibit seed germination $[22,43,49,50]$. Legume mulches have been associated with $>50 \%$ reduction in pathogenic nematode survival

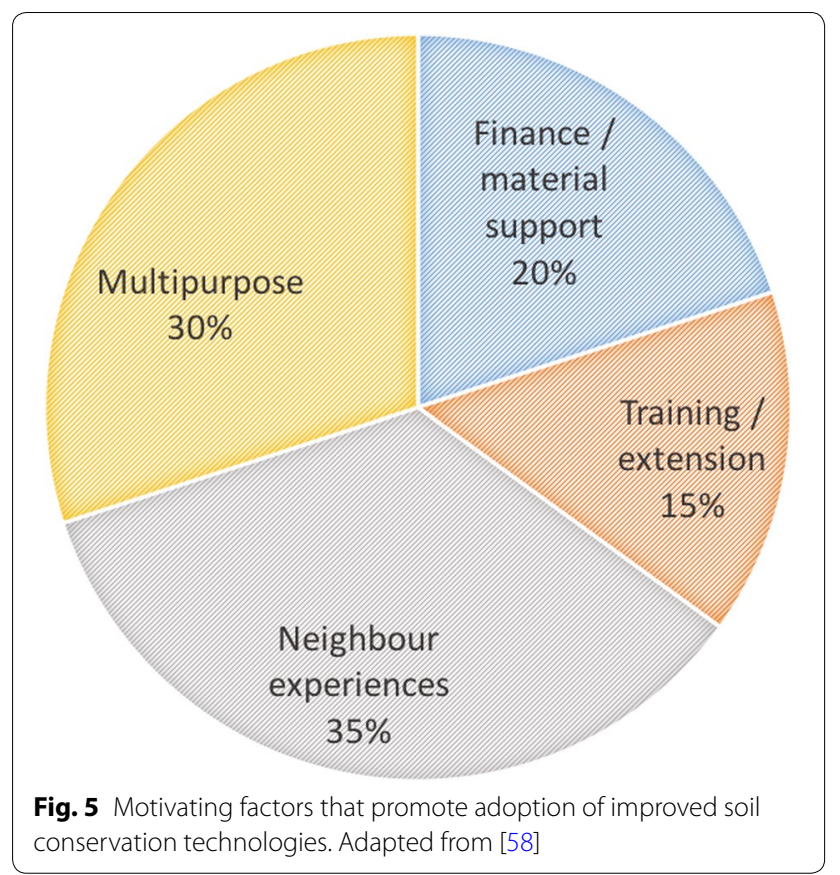

[43]. Pest and disease suppression can contribute a large proportion of the total benefits of a legume in a rotation system; a study of a pea-wheat and continuous wheat rotations observed that $91 \%$ of the yield advantage was due to non-BNF benefits, mainly by reducing leaf diseases [51].

Dry season crops provide yields at a critical time of food and feed insecurity As already noted, hundreds of millions of smallholder farmers and landless peasants suffer from seasonal malnutrition in the dry season [2]. There is an opportunity for smallholder farmers to cultivate drought-tolerant legume crops in the dry season to provide fresh organic matter, and provide a source of animal feed in the mid-hills of Nepal $[6,52]$. For example, cultivation of drought-tolerant legumes in Nepal provided more than $6.8 \mathrm{t} \mathrm{DM} \mathrm{ha}^{-1}$ of vetch and $9.2 \mathrm{t} \mathrm{DM} \mathrm{ha}^{-1}$ of biomass in the dry season, alleviating the severe seasonal livestock feed deficit [53]. In Africa, dry season cultivation of drought-tolerant legumes has been successfully introduced on a small scale in Malawi, most farmers use the legumes to feed their children [54]. Other initiatives to develop drought-tolerant crops are being driven by The International Center for Agricultural Research in Dry Areas (ICARDA) and The International Crops Research Institute for the Semi-Arid Tropics (ICRISAT) [55, 56].

\section{Limitations to the adoption of sustainable agriculture interventions}

Experimentally validated sustainable agriculture interventions that conserve soil fertility such as leguminous cover crops and green manures (CC/GM) are available to subsistence farmers; however, historically in Nepal and in the global subtropics, the adoption rates of these interventions are meager despite declining soil fertility [57-59]. A study in Nepal revealed four primary motivating factors for adoption of improved soil conservation technologies like CC/GM (Fig. 5) : neighbor experiences (35\%), multifunctionality (30\%), finance and material support (20\%), and training and extension (15\%) [58]. Furthermore, farmer surveys in the Kaski and Dhading districts of Nepal indicate that their terrace land is too dry to grow most crops including many leguminous $\mathrm{CC} /$ GM in the dry season [7].

\section{The need to diversify crop species to adapt to a changing environment}

The sustainable development and food security of smallholder communities are hindered by the reduction in species utilized in agricultural ecosystems $[6,60]$. The potential for crop failure is exacerbated by the reliance on a few plant species $[5,6,61,62]$. Plant species vary in their vulnerabilities and resistances to hazards like environmental stress including heat, cold, drought, floods, pests, 
and disease. As a result, the reliance on a few crop species is a risk for farmers [62]. Crop production in monoculture systems increases exposure to pests, diseases, and environmental stress [62]. Total crop yields are stabilized by the capacity for each individual crop species to adapt and be productive in different conditions, and hence, the intrinsic robustness of diverse agroecosystems is an asset to farmers in a changing climate [62]. The consequence of reduced agrobiodiversity can be immense for subsistence farmers whose livelihood depends on their crop yield. For example, farmer surveys in the mid-hills of Nepal indicate that the monsoon rains have been delayed by up to a month, thus reducing the growing season [7]. The unpredictable onset of the monsoon challenges farmers to utilize crops that will be productive in growing seasons of varying durations. When the growing season is delayed, the utilization of wild plants, drought-tolerant crops like millet and amaranth, and short-duration varieties, is an important adaptive strategy for subsistence farmers $[6$, 61].

\section{Examples of successful implementation of leguminous cover crops during the dry season}

A meta-analysis of studies from regions that experience seasonal dry and wet seasons throughout the global subtropics has reported significant yield, soil fertility, ecological, and agronomic benefits from the use of leguminous cover crops and green manures [63]. Another metaanalysis of sustainable land-use practices among subsistence farmers around the world found that agronomic interventions like cover cropping and the use of legumes in crop rotations had a yield advantage over conventional practices of $116 \%$ in dry areas and $122 \%$ in moist areas [64]. A study from Kenya observed an increase in maize yield from $1.2-1.8$ to $2.0 \mathrm{t} \mathrm{ha}^{-1}$ with the use of the cover crop, mucuna (Mucuna puriens) [9]. Significant short- and long-term losses in yield have been observed in regions that planted maize continuously compared to cover cropping rotations with pigeon pea (Cajanus cajan) and mucuna [65]. Farmers in Benin that adopted mucuna cover cropping attained maize yields equivalent to the application of $130 \mathrm{~kg} \mathrm{~N} \mathrm{ha}^{-1}$ [66]. The use of sunn hemp (Crotalaria juncea) and cowpea (Vigna unguiculata) as green manures in Cuba provided the equivalent of $175 \mathrm{~kg} \mathrm{~N} \mathrm{ha}^{-1}$ to squash; in addition, the green manures improved the physical and chemical characteristics of the soil [67]. Reports from Cantarranas, Honduras, indicate that subsistence farmers cultivating mucuna (M. puriens) fixed up to $150 \mathrm{~kg} \mathrm{~N} \mathrm{ha}^{-1}$, increased maize yield $300 \%$, and reduced the labor input for weeding by $75 \%$ [67]. Maintenance of soil cover by planting cover crops during the fallow period has been shown to control soil erosion on agricultural terraces in the highlands of the northern
Philippines [68]. Wheat-vetch rotations have been shown to have a number of benefits relative to wheat monocultures under drought conditions in a Mediterranean environment; these benefits included: increased yield and grain protein in the subsequent wheat crop, reduced yield reduction in wheat in the intercrop, and the production of additional animal feed and green manure [69]. Wheatannual legume rotations have been shown to significantly improve a number of parameters related to soil microbial populations relative to typical wheat-fallow management; improvements included a $385 \%$ increase in the number of soil bacteria, a $210 \%$ increase in filamentous fungi in soil, a $170 \%$ increase in microbial biomass $\mathrm{C}$ content, and a $191 \%$ increase in microbial biomass $\mathrm{N}$ content [70]. ICARDA is actively conducting research on drought-tolerant forages in Sub-Saharan Africa, South America, and Asia and the Pacific $[63,71]$, which may lead to the development of additional drought-tolerant legume crops for the dry season.

Several Brassica species have been shown to effectively suppress soil pathogens [72]. A cereal crop rotated with Vicia spp. or Lathyrus spp. reduced the pest pressure by pathogenic nematodes on the subsequent cereal crop [35]; nematodes are a common problem in the mid-hills of Nepal [73]. Biomass from jack bean (Canavalia ensiformis) and a velvet bean (Mucuna deeringiana, syn. puriens) was found to suppress $(>50 \%)$ the development of plant pathogenic nematodes in tomato roots in a greenhouse assay and exhibited a strong phytotoxic effect on weed seed germination in vitro [43]. A review of conservation agriculture in South Asia cites a number of case studies in subtropical regions that note weed suppression as a benefit of cover crop and mulch application [74].

\section{Prospecting the dry season wild plant community is an innovative strategy to promote the livelihoods of subsistence farmers in the subtropics} The value of wild plants including weeds

The conservation and maintenance of wild plants, weeds, as well as neglected and underutilized crop species, is an important strategy to promote the livelihoods of subsistence farmers, improve local resilience and sustainable development $[6,10,28,75]$. The selection of wild plant species is a starting point for the development of new crops $[6,28]$, can strengthen the role of custodian farmers in conservation efforts [76], and enhance participatory agronomic research and plant breeding [77]. The development of novel crops from wild species can also contribute to global efforts to preserve and enhance agrobiodiversity $[6,10,78]$. The development of indigenous forage legumes has been suggested as a solution for animal feed deficits [35]. Developing a cover crop from a wild plant may provide an opportunity for the creation 
of seed businesses, generate local income, stimulate local economies, and promote innovation in sustainable agriculture interventions. Furthermore, wild relatives of current staple crops are useful for the improvement and adaptation of these crops through breeding, involving introgression of novel genetic traits [79].

\section{Wild plants have potential as cover crops in the dry season}

Native and naturalized plants that persist in the dry season are naturally endowed with traits that are desirable in a cover crop, including local adaptation, a compatible life cycle, tolerance to drought and cold, resilience to pests and disease, and productivity under low external input (LEI) conditions [10]. These traits have played a role in supporting the livelihoods of subsistence farmers around the world including in Nepal [61,80-83]. Selecting cover crops from wild plants and weeds is an innovative strategy to overcome the limitations of severe drought and increase farmer adoption of a technology that reduces institutional reliance and enhances livelihoods by improving soil fertility and food security.

\section{Dry season wild plants can be optimized as cover crops through selection of diverse traits including nitrogen fixation and drought tolerance}

The crops cultivated today originated from wild plants following selection, breeding, and agronomic trials [10, 84]. Case studies from around the world [85] including Sub-Saharan Africa and Nepal $[6,86]$ have identified a list of functional traits as being important for dry season legume crops including superior drought tolerance and improved biological nitrogen fixation under drought stress [32] (Table 1).

Intra-species variation in biological nitrogen fixation has been observed throughout the legume family [30, 87] including within Glycine max (soybean) [88], Lablab purpureus [89], Vicia faba (faba bean) [90, 91], Trifolium alexandrinum (bersem clover) [36, 92-94], Phaseolus vulgaris (common bean) [95, 96], Pisum sativum (green pea) [97], V. unguiculata (cowpea) [98], and Vigna aconitifolia (mothbean) [93]. Optimizing biological nitrogen fixation involves the selection of not only the best legume genotype but also selecting the most optimal legume and rhizobia combination [30]. Since the symbiotic relationship is host specific, rhizobia strains must be selected in association with the specific plant host [30,99]. Plant species and associated rhizobia vary for drought tolerance with respect to BNF and water use efficiency (WUE) [36, 87, 100, 101]. WUE describes the amount of water used by a crop to produce a unit of biomass, or the slope of the regression of dry biomass against cumulative transpiration [102]. Nodulation,
Table 1 Traits and corresponding agroecological functions desired for an ideal cover crop

\begin{tabular}{|c|c|c|}
\hline Trait & Function & References \\
\hline Water use efficiency & Drought tolerance & {$[32]$} \\
\hline Nitrogen fixation & Plant nutrition, soil fertility & {$[32]$} \\
\hline Phosphate mineralization & Plant nutrition & {$[32]$} \\
\hline Palatability & Feed quality & {$[32]$} \\
\hline Spreading growth & Soil cover, prevent erosion & {$[32]$} \\
\hline Long roots & $\begin{array}{l}\text { Deep penetration, sequester } \\
\text { moisture }\end{array}$ & {$[121]$} \\
\hline Fibrous roots & $\begin{array}{l}\text { Bind aggregates, prevent } \\
\text { erosion }\end{array}$ & {$[23]$} \\
\hline Suppressive exudates & Suppress pests and diseases & {$[122]$} \\
\hline Seed storability & Shelf life & {$[123]$} \\
\hline Lack of dormancy & Can be planted readily & {$[123]$} \\
\hline Germination & Even canopy formation & {$[123]$} \\
\hline Inbreeding & $\begin{array}{l}\text { Homogenous populations } \\
\text { from saved seed }\end{array}$ & {$[123]$} \\
\hline Duration & $\begin{array}{l}\text { Compatibility with crop rota- } \\
\text { tion }\end{array}$ & {$[32]$} \\
\hline Regrowth & $\begin{array}{l}\text { Tolerance of trampling, graz- } \\
\text { ing, and cutting }\end{array}$ & {$[32]$} \\
\hline Naturalized & Not invasive & {$[32]$} \\
\hline Allelopathy & Suppression of weeds & {$[48]$} \\
\hline Yield & Productivity & {$[32]$} \\
\hline Low input & Labor, water, nutrients, rainfed & {$[32]$} \\
\hline
\end{tabular}

growth, and BNF can be enhanced by inoculating plants with improved and drought-tolerant rhizobia, but these strains must effectively compete with indigenous soil rhizobia for nodule occupancy [36]. The presence of root nodules is a simple indicator for whether or not indigenous or improved rhizobia are capable of infecting the legume host [103]. Combinations of plant accessions and rhizobia biovars can be evaluated by growing them in environments of varying water limitation; maintenance of BNF under water-limiting conditions can then be measured in terms of biomass, nitrogen concentration and isotopic discrimination, plant architecture, and transpiration.

\section{Wild plant selection can benefit from traditional knowledge and participatory approaches}

Selection of wild plants and subsequent improvement can benefit from the existing knowledge of local indigenous peoples. Traditional ecological knowledge (TEK) is developed through generations of experience and is rarely written down, as a result, TEK/ITK is vulnerable to loss, and there is an intrinsic value to its preservation [104]. Tacit value can be generated by developing novel interventions that utilize aspects of TEK to monitor and 


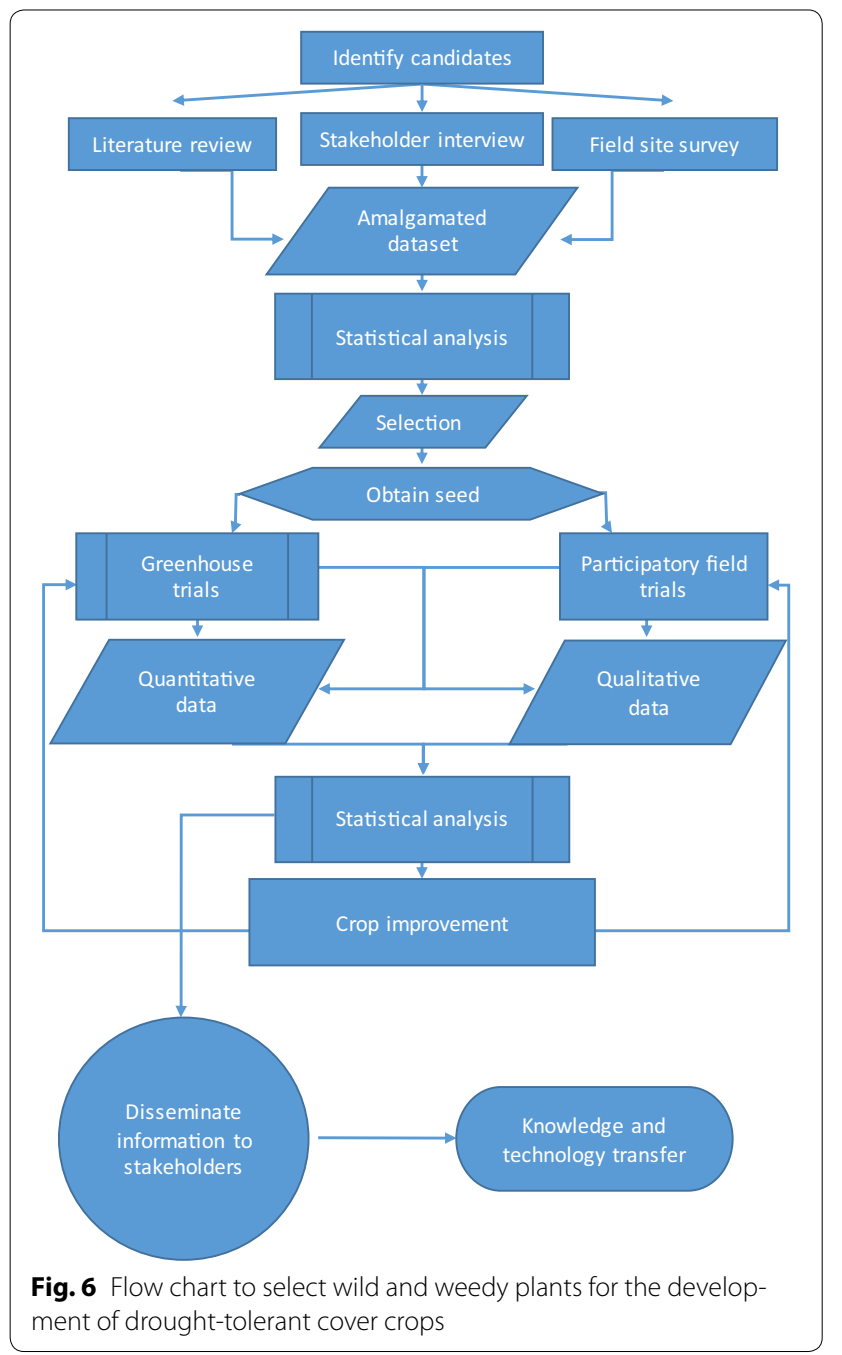

manage ecosystems [104, 105]. Botanical, agronomic, and anthropological approaches can be combined to understand and improve members of the dry season plant community $[10,106,107]$.

Mother and baby trial designs have been widely adopted in the field of participatory agronomic and plant breeding research with farmers around the world [77, 86, 108]. Mother trials involve all treatments, while baby trials involve a subset of these treatments including a control [109]. The mother-baby trial design links mother trials, which are replicated within a site, and baby trials, which are replicated only once on a site; the systematic linkage of mother and baby trials makes it possible to conduct tests under a greater variety of farm management strategies and environments [108]. The primary reason cited for the utilization of mother and baby trials is the ability to include many farmers and quickly evaluate varieties and/or technologies [108].

\section{Nepal as a case study for the selection of leguminous dry season cover crops}

Subsistence farmers in Nepal face challenges that are common to subsistence farmers in the global subtropics. In Nepal, the agriculture sector contributes 38\% of GDP and employs $82 \%$ of the labor force, of which the majority are smallholder farmers [12]. The country is small, landlocked, and encompasses the southern face of the Himalayan mountain range, with altitudes ranging from 60 to $8848 \mathrm{~m}$ [73]. The hilly regions of Nepal cover $42 \%$ of the total area [12]. The annual mean precipitation in Nepal is $1800 \mathrm{~mm}$, of which $80 \%$ occurs during the monsoon season (June to October) (Fig. 2), and at this time, the fragile landscape is particularly vulnerable to erosion, landslides, and floods [59]. There is an extended dry season from October to May, during which agricultural productivity is severely limited. As a result, there is an annual cycle of hunger, malnutrition, and livestock feed deficit. During this time, people utilize wild foods and feeds from forests and common property resources [82]. Some communities gather up to $85 \%$ of their livestock feed off-farm [59].

The farming system in the mid-hills utilizes terraces. Soils in the mid-hills of Nepal can be sandy, prone to leaching and erosion, and deficient in nitrogen; weeds are a common issue that increases the labor requirement, and plant pathogenic nematodes are a common issue causing disease and yield loss [110]. Case studies indicate a loss of soil fertility in conventional terrace cropping systems in this region [18]. Rainfed upland sloping terraces may lose up to $25 \mathrm{t} \mathrm{ha}^{-1}$ of soil annually [111]. The terrace soil is exposed to the natural elements throughout the dry season, and the bare soil is vulnerable to run off at the onset of the monsoon rains [14]. More than 50\% of the total annual soil losses in the mid-hills occur during the early monsoon period [25].

Declining soil fertility and crop productivity motivate the utilization of soil conservation practices [57]. There are a number of former and current projects to improve dry season fodder availability in the mid-hill regions of Nepal; these projects have focused on improved forage cultivation, utilizing fallow terrace land to cultivate forages, and fodder tree establishment on bund and terrace risers [59]. The Nepal Agriculture Research Council (NARC) promotes research and extension related to the conservation and promotion of native pasture species including Medicago sativa ssp. falcata, Pennisetum flaccidum, Agropyron spp, Festuca and Elymus in the dry trans-Himalayan region [59].

\section{Case studies reveal a gap in the cropping calendar}

Farmers have relatively few options in terms of dry season crops for the mid-hill regions of Nepal, because most of the land is rainfed [59]. The diverse crop calendars that 
are used in the mid-hills were compiled from surveys and the literature (Table 2). In the mid-hills region, farmer surveys and reports from agricultural extension agents indicate that most of the land is left fallow in the dry season because it is too dry to cultivate staple crops; a limited area is used for cultivation of wheat, barley, peas, mustard, and maize [6,59]. Fallow agricultural terraces are especially vulnerable to seasonal food insecurity, feed deficit, and soil erosion [18]. As a result, subsistence farmers in the mid-hills have a need for dry season crops that can produce biomass on residual moisture to provide animal feed, green manure, enhance soil fertility, and prevent erosion [18].

\section{Methodology to identify leguminous cover crop candidates for Nepal}

Three approaches were used to develop a list of candidate cover crops that are appropriate for the dry season in the mid-hills of Nepal: a literature review, stakeholder interviews, and field site visits with farmers (Fig. 6):

\section{Literature review}

First, a literature review revealed a number of candidate leguminous underutilized crops and wild plant species that are native, naturalized, or cultivated in Nepal. The literature review utilized online resources including Google Scholar, Web of Science, Feedipedia, Research Gate, and web portals to a number of governmental and nongovernmental organizations [i.e., Food and Agricultural
Organization of the United Nations (FAO), ICARDA, The International Maize and Wheat Improvement Center (CIMMYT)]. Google Scholar search terms included combinations of the following: annual, Leguminosae, Fabaceae, crop wild relative, drought tolerant, cover crop, crop rotation, intercrop, mulch, soil, erosion, nitrogen fixation, phosphate solubilization, weed suppression, allelopathy, Bitumenaria, Cajanus, Cicer, Glycine, Vicia, Vigna, Lens, Pisum, and Phaseolus. There were approximately 2000 search results that were retrieved including meta-analyses, reviews, research articles, reports, conference proceedings, and web-based knowledge portals. The criteria for the selection of literature was based on topi$\mathrm{cal}$ and regional relevance, high-quality research methodology including quantitative measurements and use of proper controls, discarding information with obvious bias and/or confounding factors. The criteria were sometimes expanded to include plant species that have a perennial life cycle, as well as plants in families other than the Leguminosae that may form symbiotic relationships with nitrogen-fixing bacteria (i.e., Cannabaceae, Myricaceae, Rosaceae, and Rhamnaceae). The identification of appropriate species was hindered by a lack of information published in scientific journals and peer-reviewed sources, vague characterization restricted to qualitative information, restricted access to online journals, unavailable digital editions, unpublished institutional research, research gaps, ambiguous terminology, linguistic barriers, semantic drift, and etymological evolution. The final

Table 2 A calendar of typical crop rotation systems in the mid-hills of Nepal

\begin{tabular}{|c|c|c|c|c|c|c|c|c|c|c|c|}
\hline Jan & Feb & Mar & Apr & May & Jun & Aug & Sept & Oct & Nov & Dec & Reference \\
\hline Wheat & & & & \multicolumn{5}{|c|}{ Wheat or finger millet } & \multicolumn{2}{|l|}{ Wheat } & [59] \\
\hline Fallow & & & & \multicolumn{7}{|c|}{ Wheat or finger millet } & {$[59]$} \\
\hline Mustard & & Fallow & \multicolumn{5}{|c|}{ Maize and soybean } & \multicolumn{3}{|l|}{ Mustard } & {$[59]$} \\
\hline \multicolumn{3}{|l|}{ Fallow } & \multicolumn{5}{|c|}{ Maize or upland rice } & \multicolumn{3}{|l|}{ Fallow } & {$[59]$} \\
\hline \multicolumn{3}{|l|}{ Wheat } & \multicolumn{5}{|c|}{ Wheat or rice } & \multicolumn{3}{|l|}{ Wheat } & {$[59]$} \\
\hline \multicolumn{3}{|l|}{ Barley } & \multicolumn{4}{|c|}{ Maize } & Fallow & & \multicolumn{2}{|l|}{ Barley } & {$[59]$} \\
\hline Wheat & & Fallow & & \multicolumn{5}{|c|}{ Rice and soybean on bunds } & Fallow & Barley & {$[124]$} \\
\hline \multicolumn{3}{|l|}{ Barley } & \multicolumn{5}{|c|}{ Maize and soybean } & Fallow & \multicolumn{2}{|l|}{ Wheat } & {$[124]$} \\
\hline Wheat & & Fallow & \multicolumn{5}{|c|}{ Rice and black gram on bunds } & \multicolumn{2}{|l|}{ Fallow } & Barley & {$[124]$} \\
\hline \multicolumn{6}{|l|}{ Fallow } & \multicolumn{2}{|l|}{ Black gram } & Fallow & \multicolumn{2}{|l|}{ Wheat } & {$[124]$} \\
\hline Wheat & & Fallow & \multicolumn{5}{|c|}{ Rice and horse gram on bunds } & \multicolumn{2}{|l|}{ Fallow } & Barley & {$[124]$} \\
\hline Barley & & Fallow & \multicolumn{5}{|c|}{ Maize and horse gram } & Fallow & \multicolumn{2}{|l|}{ Wheat } & {$[124]$} \\
\hline Wheat & & & \multicolumn{6}{|c|}{ Rice and ricebean on bunds } & & Barley & {$[124]$} \\
\hline Barley & & Fallow & \multicolumn{4}{|c|}{ Maize and ricebean } & Fallow & & \multicolumn{2}{|l|}{ Wheat } & {$[124]$} \\
\hline Peas & & Fallow & & \multicolumn{3}{|c|}{ rice } & & \multicolumn{2}{|l|}{ Fallow } & Barley & {$[124]$} \\
\hline Fallow & & Maize & & & & Fallow & Pea ar & d mustar & & & {$[124]$} \\
\hline \multicolumn{3}{|l|}{ Potato } & Maize a & nd rice & ean & & & & Potato & & This study \\
\hline Commor & bean & & & Maiz & & & & & Commo & bean & This study \\
\hline Lentil & & & & & Mai & & & & Lentil & & This study \\
\hline Faba bea & & & Fallow & Maiz & & & & & Faba be & & This study \\
\hline
\end{tabular}


table of 16 select candidate legume species was extracted from 14 references: 2 books, 2 reviews, 9 research articles, and 1 report. A number of studies have identified host specificity of rhizobia genera, species, biovars, and strains, which is relevant in this research $[99,112,113]$.

\section{Stakeholder interviews}

To facilitate the inclusion of local expertise in the selection process, interviews were conducted with local scientists, academic researchers, plant breeders, botanists, agronomists, extension agents, NGO staff and leaders of local farmer groups. Other researchers were contacted through academic and scientific social networking Web sites like Research Gate. A local research partner (Local Initiatives for Biodiversity, Research and Development, LI-BIRD) assisted with identification of knowledgeable stakeholders. The stakeholders were a valuable source of unpublished information and provided access to private libraries of relevant research. Interview questions (Additional file 1) were focused on trying to extract existing knowledge on local drought-tolerant legumes (wild, cultivated in the dry season, consumed by humans or livestock), or tips on relevant knowledge resources. A number of challenges hindered the stakeholder interviews including language barriers and the identification of active and available researchers. A large volume of research on drought-tolerant crops in Nepal and the subtropics is upward of 40 years old, and as a result, many of the research groups have dissolved and the researchers have retired.

\section{Farmer interviews}

Existing groups of subsistence farmers participating in agricultural research with a grass-root Nepalese NGO, LI-BIRD, were targeted for questioning after progress meetings. Field site visits were facilitated by accompanying researchers from LI-BIRD, and the research partners assisted with translation and identification of local flora. Farmers were questioned to extract their knowledge about drought-tolerant crops and wild plants that grow in the dry season and included surveys of annual legume plants via farm tours. The native communities of Nepal are typically knowledgeable and resourceful regarding the utilization of plants for humans and livestock [82, 114, 115].

\section{Leguminous cover crop candidates identified for Nepal}

A total of 98 legume species and subspecies were identified as candidates for the development of dry season cover crops based on the methodology described above (Additional file 2: Table S1). Data collection included the following parameters: taxonomic classification; common names (local, English); domestication and cultivation status; life cycle; morphology; root habit; value (food, feed and medicinal); naturalization status; whether it is a wild relative of a cultivated species; the ability to perform BNF and/or solubilize phosphorus; planting and harvest dates; toxicity, allelopathy; and stress tolerance (cold, drought, trampling, grazing). Available candidates were ranked using multifactor analysis (MFA) of the selected criteria and then filtered based on seed availability or the ability to multiply collected seed. Based on these criteria, the most promising candidates were identified within the genera: Cajanus, Lablab, Lens, Lathyrus, Vicia, Medicago, Trigonella, and Pisum (Table 3; Additional file 3: Table S2).

\section{Future perspectives}

Moving forward, to develop the candidate Nepalese legume species as cover crops will involve collecting seeds of diverse accessions in partnership with local stakeholders. Selection of candidate species and accessions will require evaluation of multiple traits using controlled greenhouse and field trials (Fig. 6). These traits will include: yield; efficacy as a cover crop; water use efficiency and nitrogen fixation under drought; and human and livestock palatability, digestibility, nutritional value and toxicity using feeding trials. Longer-term improvements can be

Table 3 Candidate legume species for the development of dry season cover crops for Nepal (more details in Additional file 3: Table S2)

\begin{tabular}{|c|c|c|c|c|c|}
\hline Genus & Species & English & Life cycle & Flower & Fruit \\
\hline Arachis & hypogaea & Peanut & P & Aug-Nov & Aug-Nov \\
\hline Cajanus & cajan & Pigeon pea & A & & \\
\hline Cajanus & $\begin{array}{l}\text { scarabae- } \\
\text { doies }\end{array}$ & & A & & \\
\hline Lablab & purpureus & $\begin{array}{c}\text { Bonavist } \\
\text { bean }\end{array}$ & A & Varies & Varies \\
\hline Lathyrus & aphaca & Grass pea & A & Feb-May & Feb-May \\
\hline Lathyrus & sativus & $\begin{array}{l}\text { Chickling } \\
\text { vetch }\end{array}$ & A & Feb-Apr & Feb-Apr \\
\hline Lens & culinaris & Lentil & A & Feb-Mar & Mar-Apr \\
\hline Phaseolus & vulgaris & $\begin{array}{r}\text { Kidney } \\
\text { bean }\end{array}$ & A & Feb-Apr & Feb-Apr \\
\hline Pisum & sativum & Pea & A & Jan-Mar & Jan-Mar \\
\hline Trigonella & $\begin{array}{l}\text { foenum } \\
\text {-graecum }\end{array}$ & Fenugreek & A & & \\
\hline Vicia & angustifolia & $\begin{array}{l}\text { Clover } \\
\text { vetch }\end{array}$ & A & Sept-Nov & Dec-Feb \\
\hline Vicia & sativa & $\begin{array}{l}\text { Common } \\
\text { vetch }\end{array}$ & A & Sept-Nov & Dec-Feb \\
\hline Vicia & hirsuta & Hairy vetch & A & Dec-Mar & Apr-May \\
\hline Vigna & mungo & Black gram & A & Varies & Varies \\
\hline Vigna & unguiculata & Cowpea & A & June-Oct & June-Oct \\
\hline Vigna & umbellata & Ricebean & A & June-Oct & June-Oct \\
\hline
\end{tabular}

$A$ annual, $P$ perennial 
made through breeding, crossing with domestic relatives and identification of optimal rhizobia strain combinations. This entire process should take advantage of participatory approaches with local stakeholders, especially female subsistence farmers. To scale up, seed multiplication can be conducted on-farm as a value-added activity [116]. The development of smallholder seed enterprises is a proven strategy with success stories from around the world [76, 117-119]. Seasonal migration can be further mitigated by creating local job opportunities in rural non-farm enterprises like the manufacturing of machinery specialized for dry season cropping (e.g., planters and weeders) [120].

\section{Conclusions}

Here we (1) reviewed the agroecological challenges of the dry season for subsistence farmers in the subtropics; (2) explained the benefits of biological nitrogen fixation and leguminous cover crops; and (3) provided a framework for the selection of leguminous cover crop species-with the goal of assisting policy makers and social makers, to help mitigate food and feed insecurity during the dry season in the subtropics. The framework was applied to identify 78 candidate dry season leguminous cover crop species for the mid-hills of Nepal based on a literature review, stakeholder interviews, and field site visits with farmers. It is hoped that this framework will serve as a model to benefit subsistence farmers in subtropical regions throughout the world.

\section{Additional files}

Additional file 1. Survey questions: Example questions for farmer surveys used in Nepal.

Additional file 2. Short list of candidate cover crop species for the midhills of Nepal.

Additional file 3. Full list of candidate cover crop species for the mid-hills of Nepal.

\section{Abbreviations}

BNF: biological nitrogen fixation; DM: dry matter; GDP: gross domestic product; Ha: hectare; K: potassium; N: nitrogen; P: phosphorus.

\section{Authors' contributions}

FAAS co-conceived the study; acquired, analyzed and interpreted all the data; and drafted the manuscript. MNR co-conceived the study and revised the manuscript. Both authors read and approved the final manuscript.

\section{Acknowledgements}

The authors are grateful to our Nepalese NGO partner, LI-BIRD, in particular B.B. Tamang, Durga Nariyan Shreshtha, Roshan Pudasaini, and Rajeev Dhakal. FAAS is most grateful for the many generous Nepalese farmers who graciously invited him into their lives during his field work in Kaski, Tanahun, Lamjung, Gorkha, and Dhading districts. We thank researchers at the Nepal Agricultural Research Center in Kumaltar, Bandipur, and Lumle, Nepal. We wish to acknowledge the struggle of the Nepalese people in the aftermath of the 2015 Himalayan earthquakes. We thank Kevin Tiessen (IDRC, Ottawa) for his enthusiastic support of this project.

\section{Competing interests}

Neither the authors nor the University of Guelph received payment or services from a third party for any aspect of the submitted work. No financial relationships exist with any entities that could be perceived to influence the submitted work. There are no patents or copyrights relevant to this work. There are no relationships or activities to disclose that could be perceived to have influence the submitted work.

\section{Availability of data and materials}

All relevant data have been included as supplementary material.

\section{Funding}

Funding was generously granted by the CIFSRF program, jointly funded by the International Development Research Centre (Ottawa) and Global Affairs Canada. The funding body had no role in the design of the study or the collection, analysis, or interpretation of the data.

Received: 2 September 2016 Accepted: 11 February 2017

Published online: 06 March 2017

References

1. Grace K, Davenport F, Funk C, Lerner AM. Child malnutrition and climate in Sub-Saharan Africa: an analysis of recent trends in Kenya. Appl Geogr. 2012;35(1):405-13.

2. Vaitla B, Devereux S, Swan SH. Seasonal hunger: a neglected problem with proven solutions. PLoS Med. 2009;6(6):e1000101.

3. Jankowska MM, Lopez-Carr D, Funk C, Husak GJ, Chafe ZA. Climate change and human health: spatial modeling of water availability, malnutrition, and livelihoods in Mali Africa. Appl Geogr. 2012;33:4-15.

4. Panthi J, Dahal P, Shrestha ML, Aryal S, Krakauer NY, Pradhanang SM, Lakhankar T, Jha AK, Sharma M, Karki R. Spatial and temporal variability of rainfall in the Gandaki River Basin of Nepal Himalaya. Climate. 2015;3(1):210-26.

5. Morton JF. The impact of climate change on smallholder and subsistence agriculture. Proc Natl Acad Sci. 2007;104(50):19680-5.

6. IDRC. Revalorising small millets in rainfed regions of South Asia. IDRC Final Technical Report 2014. http://idl-bnc.idrc.ca/dspace/bitstream/10625/53589/1/IDL-53589.pdf. Accessed 11 Nov 2015.

7. Kahane R, Hodgkin T, Jaenicke H, Hoogendoorn C, Hermann M, Hughes JD, Padulosi S, Looney N. Agrobiodiversity for food security, health and income. Agron Sustain Dev. 2013;33(4):671-93.

8. Department of Economics, United Nations. The millennium development goals report 2009. http://www.un.org/millenniumgoals/reports. shtml. Accessed 10 Apr 2015.

9. Kaumbutho P, Kienzle J. Conservation agriculture as practiced in Kenya: two case studies. African Conservation Tillage Network and Food and Agriculture Organization of the United Nations, Nairobi; 2007. http:// www.fao.org/ag/ca/doc/Kenya_casestudy.pdf. Accessed 21 May 2016.

10. Dempewolf H, Eastwood RJ, Guarino L, Khoury CK, Müller JV, Toll J. Adapting agriculture to climate change: a global initiative to collect, conserve, and use crop wild relatives. Agroecol Sustain Food Syst. 2014;38(4):369-77.

11. Lowder SK, Skoet J, Singh S. What do we really know about the number and distribution of farms and family farms in the world? ESA Working Paper No. 14-02. Food and Agriculture Organization of the United Nations; 2014. http://www.fao.org/economic/esa. Accessed 01 Jan 2016.

12. Regmi BR, Adhikari A. Country case study-Nepal. Human Development Report Office, United Nations Development Programme; 2007. http:// hdr.undp.org/en/reports/global/hdr2007-2008/papers. Accessed 15 Sept 2015.

13. Mancosu N, Snyder RL, Kyriakakis G, Spano D. Water scarcity and future challenges for food production. Water. 2015;7(3):975-92.

14. Gardner RA, Gerrard AJ. Runoff and soil erosion on cultivated rainfed terraces in the Middle Hills of Nepal. Appl Geogr. 2003;23(1):23-45.

15. Young A. Land degradation in South Asia: its severity, causes and effects upon the people. Food and Agriculture Organization of the United Nations; 1994. http://aims.fao.org/serials/s_984. Accessed 22 Sept 2015. 
16. Kyuma K. (2009). Nature and Agriculture in Monsoon Asia. Paper presented at MARCO symposium: challenges for agro-environmental research in monsoon Asia, Japan; 2009. http://www.niaes.affrc.go.jp/ marco/marco2009/english/program/S-0_Keynote_Kyuma_Kazutake. pdf. Accessed 13 Mar 2015.

17. Kang BT. Soil tillage in Africa: needs and challenges. Food and Agriculture Organization of the United Nations; 1993. p. 69. http://hdl.handle. net/10919/65448. Accessed 3 Nov 2015.

18. Das R, Bauer S. Bio-economic analysis of soil conservation technologies in the mid-hill region of Nepal. Soil Tillage Res. 2012. doi:10.1016/j. still.2012.01.016

19. Pachauri RK, Allen MR, Barros VR, Broome J, Cramer W, Christ R, Church JA, Clarke L, Dahe Q, Dasgupta P, Dubash NK. Climate change 2014: synthesis report. Contribution of working groups I, II and III to the fifth assessment report of the intergovernmental panel on climate change. IPCC; 2014.

20. Zuazo VD, Pleguezuelo CR, Peinado FM, De Graaff J, Martínez JF, Flanagan DC. Environmental impact of introducing plant covers in the taluses of terraces: implications for mitigating agricultural soil erosion and runoff. Catena. 2011;84(1):79-88.

21. Watson HR, Partap T. Sloping agricultural land technology (SALT): a regenerative option for sustainable mountain farming. Kathmandu: International Center for Integrated Mountain Development (ICIMOD); 1994.

22. Busscher WJ, Reeves DW, Kochhann RA, Bauer PJ, Mullins GL, Clapham WM, Kemper WD, Galerani PR. Conservation farming in southern Brazil: using cover crops to decrease erosion and increase infiltration. J Soil Water Conserv. 1996;51(3):188-92.

23. Olson KR, Ebelhar SA, Lang JM. Cover crop effects on crop yields and soil organic carbon content. Soil Sci. 2010;175(2):89-98.

24. Chen G, Weil RR. Penetration of cover crop roots through compacted soils. Plant Soil. 2010;331(1-2):31-43.

25. Quamruzzaman M, Rao AS, Reddy KS, Sherchan DP, Karki KB, Sherchan DP, Karki KB. Improving plant nutrient management for better farmer livelihoods, food security and environmental sustainability. Rome: Rap Publication. Food and Agriculture Organization of the United Nations; 2006. p. 58-72.

26. Jensen ES, Hauggaard-Nielsen $\mathrm{H}$. How can increased use of biological N2 fixation in agriculture benefit the environment? Plant Soil. 2003:252(1):177-86

27. Food and Agricultural Organization of the United Nations, Statistics Division. FAOSTAT, trade, crops and livestock products. 2012. http:// faostat3.fao.org/browse/T/TP/E. Accessed 21 Jan 2016.

28. Mayes S, Massawe FJ, Alderson PG, Roberts JA, Azam-Ali SN, Hermann $M$. The potential for underutilized crops to improve security of food production. J Exp Bot. 2012;63(3):1075-9.

29. Peoples MB, Herridge DF, Ladha JK. Biological nitrogen fixation: an efficient source of nitrogen for sustainable agricultural production? Plant Soil. 1995:174(1-2):3-28.

30. Hardarson G, Atkins C. Optimising biological N2 fixation by legumes in farming systems. Plant Soil. 2003;252(1):41-54.

31. Chapagain T, Riseman A. Intercropping wheat and beans: effects on agronomic performance and land productivity. Crop Sci. 2014;54(5):2285-93.

32. Bunch R. Restoring the Soil: A guide for using green manure/cover crops to improve the food security for smallholder farmers. Canadian Foodgrains Bank; 2012. www.fao.org/ag/ca/CA-Publications/Restoring_the_Soil.pdf. Accessed 10 Sept 2015.

33. Lindström K, Murwira M, Willems A, Altier N. The biodiversity of beneficial microbe-host mutualism: the case of rhizobia. Res Microbiol. 2010;161(6):453-63.

34. Davey AG, Simpson RJ. Nitrogen fixation by subterranean clover at varying stages of nodule dehydration I. Carbohydrate status and short-term recovery of nodulated root respiration. J Exp Bot. 1990;41(9):1175-87.

35. Ates S, Feindel D, El Moneim A, Ryan J. Annual forage legumes in dryland agricultural systems of the West Asia and North Africa Regions: research achievements and future perspective. Grass Forage Sci. 2014;69(1):17-31.

36. Zahran $\mathrm{HH}$. Rhizobium-legume symbiosis and nitrogen fixation under severe conditions and in an arid climate. Microbiol Mol Biol Rev. 1999;63(4):968-89.
37. Graham PH. Stress tolerance in Rhizobium and Bradyrhizobium and nodulation under adverse soil conditions. Can J Microbiol. 1992;38(6):475-84.

38. Jenkins MB, Virginia RA, Jarrell WM. Ecology of fast-growing and slowgrowing mesquite-nodulating rhizobia in Chihuahuan and Sonoron Desert ecosystems. Soil Sci Soc Am J. 1989;53(2):543-9.

39. Mabrouk Y, Belhadj O. Enhancing the biological nitrogen fixation of leguminous crops grown under stressed environments. Afr J Biotechnol. 2012;11(48):10809-15.

40. Mrunalini A, Snehalatha C. Drudgery experiences of gender in crop production activities. J Agric Sci. 2010;1(1):49-51.

41. Pimentel D, Hepperly P, Hanson J, Douds D, Seidel R. Environmental, energetic, and economic comparisons of organic and conventional farming systems. Bioscience. 2005;55(7):573-82.

42. Bridge J. Nematode management in sustainable and subsistence agriculture. Annu Rev Phytopathol. 1996;34(1):201-25.

43. Caamal-maldonado JA, Jimenez-Osornio JJ, Torres-barraga A, Anaya $A L$. The use of allelopathic legume cover and mulch species for weed control in cropping systems. Agron J. 2001;93:27-36.

44. Govaerts B, Mezzalama M, Sayre KD, Crossa J. Long-term consequences of tillage, residue management, and crop rotation on maize/wheat root rot and nematode populations in subtropical highlands. Appl Soil Ecol. 2006;32(3):305-15.

45. Davis RA, Huggins DR, Cook JR, Paulitz TC. Nitrogen and crop rotation effects on fusarium crown rot in no-till spring wheat. Can J Plant Pathol. 2009:31(4):456-67.

46. Kirkegaard JA, Sarwar M. Biofumigation potential of brassicas: I. Variation in glucosinolate profiles of diverse field-grown brassicas. Plant Soil. 1998;201(1):71-89.

47. Liebman M, Dyck E. Crop rotation and intercropping strategies for weed management. Ecol Appl. 1993;3(1):92-122.

48. Moradi H, Sheikhpour S, Fahramand M, Keshtehgar A, Rigi K. Effect of allelopathy on crop weeds control. Int J Agric Crop Sci. 2013;6(21):1426.

49. Bond W, Grundy AC. Non-chemical weed management in organic farming systems. Weed Res. 2001;41(5):383-405.

50. Lawley YE, Teasdale JR, Weil RR. The mechanism for weed suppression by a forage radish cover crop. Agron J. 2012;104(2):205.

51. Stevenson FC, Kessel CV. The nitrogen and non-nitrogen rotation benefits of pea to succeeding crops. Can J Plant Sci. 1996;76(4):735-45.

52. Chalise SR, Khanal NR. Erosion processes and their implications in sustainable management of watersheds in Nepal Himalayas. IAHS Publ. no. 246, 1997. http://hydrologie.org/redbooks/a246/iahs_246_0325.pdf. Accessed 11 Sept 2015.

53. Schulz S, Keatinge JD, Wells G, Shrestha R. Effect of legume management on forage production and residual effects on upland rice. J Agron Crop Sci. 2000;184:173-80.

54. Kerr R, Snapp SM, Shumba L, Msachi R. Participatory research on legume diversification with Malawian smallholder farmers for improved human nutrition and soil fertility. Exp Agric. 2007;43(04):437-53.

55. ICARDA Annual Report 2014. International Center for Agricultural Research in the Dry Areas, Beirut, Lebanon; 2014

56. Winter-Nelson A, Mazvimavi K. Economic impact evaluation of the ICRISAT Jewels. Hyderabad: International Crops Research Institute for the Semi-Arid Tropics; 2014. p. 40.

57. Paudel GS, Thapa GB. Impact of social, institutional and ecological factors on land management practices in mountain watersheds of Nepal. Appl Geogr. 2004;24(1):35-55.

58. Tiwari KR, Sitaula BK, Nyborg ILP, Paudel GS. Determinants of farmers' adoption of improved soil conservation technology in a Middle Mountain Watershed of Central Nepal. Environ Manag. 2008:42(2):210-22.

59. Pariyar D. Country pasture/forage resource profiles. Rome: Food and Agriculture Organization (FAO); 2008.

60. Khoury CK, Bjorkman AD, Dempewolf H, Ramirez-Villegas J, Guarino $L$, Jarvis A, Struik PC, et al. Increasing homogeneity in global food supplies and the implications for food security. Proc Natl Acad Sci USA. 2014:111:4001-6.

61. Smith ML. How ancient agriculturalists managed yield fluctuations through crop selection and reliance on wild plants: An example from central India. Econ Bot. 2006;60(1):39-48.

62. Napel JT, Bianchi FJ, Bestman M. Utilising intrinsic robustness in agricultural production systems: inventions for a sustainable development of 
agriculture. In: Inventions for the sustainable development of agriculture. 2006. TransForum Agro \& Groen. p. 32-53.

63. Brouder SM, Gomez-Macpherson H. The impact of conservation agriculture on smallholder agricultural yields: a scoping review of the evidence. Agric Ecosyst Environ. 2014. doi:10.1016/j.agee.2013.08.010.

64. Branca G, McCarthy N, Lipper L, Jolejole MC. Climate-smart agriculture: a synthesis of empirical evidence of food security and mitigation benefits from improved cropland management. Mitig Clim Change Agric Ser. 2011;3:1-42.

65. Chabi-Olaye A, Nolte C, Schulthess F, Borgemeister C. Short-term effects of cover crops on stem borers and maize yield in the humid forest of southern Cameroon. In: Bationo A, Waswa B, Kihara J, Kimetu J (eds) Advances in integrated soil fertility management in sub-Saharan Africa: challenges and opportunities. Springer, Dordrecht; 2007. p. 195-99.

66. Pretty JN, Hine R. Reducing food poverty with sustainable agriculture: a summary of new evidence. Final report: SAFE-World Research Project. University of Essex, Colchester; 2001.

67. Altieri M. Applying agroecology to enhance the productivity of peasant farming systems in Latin America. Environ Dev Sustain. 1999. doi:10.102 3/A:1010078923050

68. Magcale-Macandog D, Ocampo LJ. Indigenous strategies of sustainable farming systems in the highlands of northern Philippines. J Sustain Agric. 2005;26(2):117-38.

69. Dalias P. Increased yield surplus of vetch-wheat rotations under drought in a Mediterranean environment. Sci World J. 2012 doi:10.1100/2012/658518.

70. Biederbeck VO, Zentner RP, Campbell CA. Soil microbial populations and activities as influenced by legume green fallow in a semiarid climate. Soil Biol Biochem. 2005. doi:10.1016/j.soilbio.2005.02.011.

71. Amri A, Damania A. Promoting community-driven conservation and sustainable use of dryland agrobiodiversity. Promoting community-driven conservation and sustainable use of dryland agrobiodiversity. International Center for Agricultural Research in Dry Areas; 2005. https://erc.undp.org/ evaluation/documents/download/849. Accessed 21 Sept 2015.

72. Larkin RP, Griffin TS. Control of soilborne potato diseases using Brassica green manures. Crop Prot. 2007. doi:10.1016/j.cropro.2006.10.004.

73. RRC.AP. State of environment. 2001. Rrcap.ait.asia. Accessed 2 Feb 2015.

74. Nawaz A, Wakeel A, Saharawat YS, Farooq M. Conservation agriculture in south Asia. In: Farooq M, Siddique KHM (eds) Conservation agriculture. Berlin: Springer; 2015. p. 249-83.

75. Hawtin G. Underutilized plant species research and development activities-review of issues and options. Rome: GFU/ICUC. International Plant Genetic Resources Institute; 2007.

76. Sthapit S, Meldrum G, Padulosi S, Bergamini N. Strengthening the role of custodian farmers in the national conservation programme of Nepal: proceedings from the national workshop, 31 July to 2 August 2013, Pokhara, Nepal.

77. Gyawali S, Sunwar S, Subedi M, Tripathi M, Joshi KD, Witcombe JR. Collaborative breeding with farmers can be effective. Field Crops Res. 2007. doi:10.1016/j.fcr.2006.09.013.

78. Brumlop S, Reichenbecher W, Tappeser B, Finckh MR. What is the SMARTest way to breed plants and increase agrobiodiversity? Euphytica. 2013. doi:10.1007/s10681-013-0960-9.

79. Grandillo S. Introgression libraries with wild relatives of crops. In: Genomics of plant genetic resources. Netherlands: Springer; 2014. p. 87-122.

80. Aryal KP, Berg Å, Ogle B. Uncultivated plants and livelihood support-a case study from the Chepang people of Nepal. Ethnobot Res Appl. 2009;7:409-22.

81. Bharucha Z, Pretty J. The roles and values of wild foods in agricultural systems. Philos Trans R Soc Lond Ser B Biol Sci. 2010;365:2913-26.

82. Uprety Y, Poudel RC, Shrestha KK, Rajbhandary S, Tiwari NN, Shrestha UB, Asselin H. Diversity of use and local knowledge of wild edible plant resources in Nepal. J Ethnobiol Ethnomed. 2012. doi:10.1186/1746-4269-8-16.

83. Thapa LB, Dhakal TM, Chaudhary R. Wild edible plants used by endangered \& indigenous Raji Tribe in Western Nepal. Int J Appl Sci Biotechnol. 2014;2(3):243-52.

84. Larson G, Piperno DR, Allaby RG, Purugganan MD, Andersson L, Arroyo-Kalin M, Doust AN, et al. Current perspectives and the future of domestication studies. Proc Natl Acad Sci. 2014;111(17):6139-46.
85. Pannell DJ, Llewellyn RS, Corbeels M. The farm-level economics of conservation agriculture for resource-poor farmers. Agric Ecosyst Environ. 2014;187:52-64.

86. Tiwari TP, Ortiz-Ferrara G, Urrea C, Katuwal RB, Koirala KB, Prasad RC, Thapa M, et al. Rapid gains in yield and adoption of new maize varieties for complex hillside environments through farmer participation. II. Scaling-up the adoption through community-based seed production (CBSP). Field Crops Res. 2009. doi:10.1016/j.fcr.2008.11.007.

87. Serraj R, Sinclair TR, Purcell LC. Symbiotic N2 fixation response to drought. J Exp Bot. 1999. doi:10.1093/jxb/50.331.143.

88. Gil-Quintana E, Larrainzar E, Seminario A, Díaz-Leal JL, Alamillo JM, Pineda M, González EM, et al. Local inhibition of nitrogen fixation and nodule metabolism in drought-stressed soybean. J Exp Bot. 2013. doi:10.1093/jxb/ert074.

89. Guretzki S, Papenbrock J. Characterization of Lablab purpureus regarding drought tolerance, trypsin inhibitor activity and cyanogenic potential for selection in breeding programmes. J Agron Crop Sci. 2014. doi:10.1111/jac.12043.

90. Katerji N, Mastrorilli M, Lahmer FZ, Maalouf F, Oweis T. Faba bean productivity in saline-drought conditions. Eur J Agron. 2011. doi:10.1016/j. eja.2011.03.001.

91. Schwenke GD, Peoples MB, Turner GL, Herridge DF. Does nitrogen fixation of commercial, dryland chickpea and faba bean crops in northwest New South Wales maintain or enhance soil nitrogen? Aust J Exp Agric. 1998. doi:10.1071/EA97078.

92. Saia S, Amato G, Frenda AS, Giambalvo D, Ruisi P. Influence of arbuscular mycorrhizae on biomass production and nitrogen fixation of berseem clover plants subjected to water stress. PLOS ONE. 2014. doi:10.1371/ journal.pone.0090738.

93. Soni P, Sharma R, Rizwan M, Singh G. Optimization of screening protocol for evaluation of drought tolerance in Vigna aconitifolia using hydroponic system. Indian Res J Genet Biotechnol. 2014;6(4):617-28.

94. Tuberosa R. Phenotyping for drought tolerance of crops in the genomics era. Front Physiol. 2012. doi:10.3389/fphys.2012.00347.

95. Chapagain T. Intercropping wheat and barley with nitrogen fixing legume species in low input organic systems. Doctoral dissertation. University of British Columbia; 2014.

96. Chapagain T, Riseman A. Barley-pea intercropping: Effects on land productivity, carbon and nitrogen transformations. Field Crops Res. 2014. doi:10.1016/j.fr.2014.06.014.

97. Chapagain T, Riseman A. Nitrogen and carbon transformations, water use efficiency and ecosystem productivity in monocultures and wheatbean intercropping systems. Nutr Cycl Agroecosyst. 2014. doi:10.1007/ s10705-014-9647-4.

98. Gomes Da Silveira JA, Da Costa RCL, Oliveira JTA. Drought-induced effects and recovery of nitrate assimilation and nodule activity in cowpea plants inoculated with Bradyrhizobium spp. under moderate nitrate level. Braz J Microbiol. 2001. doi:10.1590/S1517-83822001000300005.

99. Mutch LA, Young JPW. Diversity and specificity of Rhizobium leguminosarum biovar viciae on wild and cultivated legumes. Mol Ecol. 2004. doi:10.1111/j.1365-294X.2004.02259.x.

100. Kittlitz $V$, Amede T, Schubert S. Differential drought responses of faba bean Vicia faba L. inbred lines. J Agron Crop Sci. 1999;183:35-45.

101. Barker DJ, Caradus JR. Adaptation of forage species to drought. In: Proceedings, 19 international grassland congress. Sao Paulo, Brazil; 2001. p. 241-46.

102. Liu F, Stützel H. Biomass partitioning, specific leaf area, and water use efficiency of vegetable amaranth (Amaranthus spp.) in response to drought stress. Sci Hortic. 2004. doi:10.1016/j.scienta.2003.11.014.

103. Herder $G$, Parniske $M$. The unbearable naivety of legumes in symbiosis. Curr Opin Plant Biol. 2009;12(4):491-9.

104. Huntington HP. Using traditional ecological knowledge in science: methods and applications. Ecol Appl. 2000;10(5):1270-4.

105. Berkes F, Colding J, Folke C. Rediscovery of traditional ecological knowledge as adaptive management. Ecol Appl. 2000;10(5):1251-62.

106. Whitton J, Wolf DE, Arias DM, Snow AA, Rieseberg LH. The persistence of cultivar alleles in wild populations of sunflowers five generations after hybridization. Theor Appl Genet. 1997. doi:10.1007/ s001220050529.

107. Dawson JC, Murphy KM, Jones SS. Decentralized selection and participatory approaches in plant breeding for low-input systems. Euphytica. 2008. doi:10.1007/s10681-007-9533-0. 
108. Bellon MR, Reeves J. Quantitative analysis of data from participatory methods in plant breeding. Mexico: International Maize and Wheat Improvement Center (CIMMYT); 2002.

109. Snapp S. Mother and baby trials: a novel trial design being tried out in Malawi. Target Newsl South Afr Soil Fertil Netw. 1999;17:8.

110. Shrestha B, Maskey SL, Shrestha RK, Tripathi BP, Khadga YJ, Munankarmy RC, Bhattarai EM, Shrestha SP. Soil fertility management: farmers practices and perceptions in the hills of Nepal. Lumle technical paper. 2000.

111. International Centre for Integrated Mountain Development (ICIMOD). Good practices in watershed management: lessons learned in the mid hills of Nepal. http://lib.icimod.org/record/22078. Accessed 17 Mar 2015 .

112. Jorrin B, Imperial J. Population genomics analysis of legume host preference for specific rhizobial genotypes in the Rhizobium leguminosarum bv. viciae Symbioses. Mol Plant Microbe Interact. 2015;3:310-8.

113. Laguerre G, Louvrier P, Allard MR, Amarger N. Compatibility of rhizobial genotypes within natural populations of Rhizobium leguminosarum biovar viciae for nodulation of host legumes. Appl Environ Microbiol. 2003. doi:10.1128/AEM.69.4.2276-2283.2003.

114. Dangol DR. Traditional uses of plants of commonland habitats in Western Chitwan, Nepal. J Inst Agric Anim Sci. 2012;29:71-8.

115. Shrestha PM, Dhillion SS. Diversity and traditional knowledge concerning wild food species in a locally managed forest in Nepal. Agrofor Syst. 2006. doi:10.1007/s10457-005-6642-4.

116. Boelt B, Julier B, Karagić $Đ$, Hampton J. Legume seed production meeting market requirements and economic impacts. Crit Rev Plant Sci. 2015;34(1-3):412-27.

117. CARE. Sustainable market engagement: Ethiopian farmers' participation in informal seed multiplication. Report, 2011. http://www.CARE.org. Accessed 2 Mar 2015.
118. De BoefWS, Dempewolf H, Byakweli JM, Engels JM. Integrating genetic resource conservation and sustainable development into strategies to increase the robustness of seed systems. J Sustain Agric. 2010:34(5):504-31.

119. Neate PJ, Guei RG. Promoting the growth and development of smallholder seed enterprises for food security crops: best practices and options for decision making. Rome: Food and Agriculture Organization of the United Nations (FAO); 2010.

120. Binns P. Opportunities and challenges facing farmers in transitioning to a green economy agriculture practice. Nairobi: United Nations Environment Programme (UNEP); 2012.

121. Chaves MM, Maroco JP, Pereira JS. Understanding plant responses to drought-from genes to the whole plant. Funct Plant Biol. 2003;30(3):239-64.

122. Raaijmakers JM, Paulitz TC, Steinberg C, Alabouvette C, Moënne-Loccoz Y. The rhizosphere: a playground and battlefield for soilborne pathogens and beneficial microorganisms. Plant Soil. 2009;321(1-2):341-61.

123. Heywood V, Casas A, Ford-Lloyd B, Kell S, Maxted N. Conservation and sustainable use of crop wild relatives. Agric Ecosyst Environ. 2007:121(3):245-55.

124. Rachie KO, Bharati MP. A consultancy report on pulse improvement in Nepal. Kathmandu: Department of Agriculture; 1985.

\section{Submit your next manuscript to BioMed Central and we will help you at every step:}

- We accept pre-submission inquiries

- Our selector tool helps you to find the most relevant journal

- We provide round the clock customer support

- Convenient online submission

- Thorough peer review

- Inclusion in PubMed and all major indexing services

- Maximum visibility for your research

Submit your manuscript at www.biomedcentral com/submit 